ADDICTION BIOLOGY 16, 163-165 (2011)

HUMAN/CLINICAL STUDY: BRIEF REPORT

\title{
NMDA RECEPTORS IN FRONTAL CORTEX AND HIPPOCAMPUS OF ALCOHOL CONSUMERS
}

Eulalia Villegas $^{1 *}$, Ramon Estruch ${ }^{1,2}$, Guadalupe Mengod $^{3} \&$ Roser Cortés ${ }^{3}$

1) Department of Internal Medicine, Hospital Clínic, Barcelona, Spain

2) CIBEROBN Fisiopatología de la Obesidad y la Nutrición, Instituto de Salud Carlos III, Spain

3) Department of Neurochemistry and Neuropharmacology, IIBB, CSICIDIBAPS, CIBERNED, Barcelona, Spain.

Correspondence to:

*Eulalia Villegas, M.D. Current address:

Hospital Dos de Maig

Dos de Maig 301

08025 Barcelona, Spain

E-mail: eulalia.villegas@sanitatintegral.org 


\section{NMDA RECEPTORS IN FRONTAL CORTEX AND HIPPOCAMPUS OF ALCOHOL CONSUMERS}

Eulalia Villegas $^{1 \star}$, Ramon Estruch $^{1,2}$, Guadalupe Mengod $^{3}$ \& Roser Cortés ${ }^{3}$

Key words: Alcoholism, glutamate receptors, human brain, MK801, radioligand binding, receptor autoradiography.

\section{ABSTRACT}

Specific binding of $\left[{ }^{3} \mathrm{H}\right] \mathrm{MK} 801$ to $\mathrm{N}$-methyl-D-aspartate (NMDA) receptors in the frontal cortex and hippocampus (CA1 and gyrus dentatus) was measured by receptor autoradiography in 16 Caucasian chronic alcohol consumers free of clinical manifestations of alcoholism, and compared to 16 Caucasian control subjects. Binding densities were not significantly different between heavy and moderate drinkers, neither between alcohol consumers that were abstinent or non-abstinent before death, nor between ethanol drinkers and controls. Continued alcohol consumption, in the absence of hepatic, neurologic or psychiatric disorders related to alcoholism, does not alter the binding properties of NMDA receptors in the brain areas studied.

Running head short title: "NMDA receptors in alcohol consumers" 
A number of studies have suggested that, at least partially, alcohol-induced brain damage associated to chronic alcohol consumption is mediated through changes in glutamatergic NMDA receptors. This is supported, by the effects of drugs such as acamprosate, a partial NMDA antagonist used in relapse prevention in alcohol-dependent patients (Hammarberg et al., 2009). Only few studies have addressed the analysis of glutamate receptors in relation to alcohol abuse in humans and have provided controversial results (Cummings et al. 1990; Dodd et al. 1992; Freund \& Anderson 1996, 1999; Ridge et al. 2008). Our hypothesis is that permanent neuronal damage produced by chronic alcohol consumption is in part due to progressive changes in NMDA receptors, and that these changes might develop before the beginning of clinical manifestations of chronic alcoholism, including dependence, craving and abstinence. Thus, we assessed here the density of NMDA receptors in frontal cortex and hippocampus -brain areas known to be notably affected by chronic alcohol consumption- in a group of 16 alcohol consumers (AC) (16 male, mean age $58 \pm 12$ years, post-mortem delay $19 \pm 8$ hours) in comparison to a control group of 16 non-drinkers (14 male and 2 female, mean age $60 \pm 12$ years, postmortem delay $17 \pm 5$ hours) using autoradiographic techniques with the specific NMDA-antagonist $\left.{ }^{3} \mathrm{H}\right] \mathrm{MK} 801$. AC subjects included had not suffered any hepatic, neurologic or psychiatric disorders related to alcoholism. They were classified as moderate consumers (40 to $80 \mathrm{~g}$ of absolute alcohol daily for at least 10 years) or heavy consumers (more than $80 \mathrm{~g}$ of absolute alcohol daily for at least 10 years, enough to develop chronic alcoholic pathology). We also discriminated between AC cases that were abstinent (alcohol withdrawal minimum one week before death) or non-abstinent (last ethanol ingestion less than 12 hours before death). In consequence, it is unlikely that these subjects would undergo a withdrawal situation that could eventually involve acute changes in NMDA receptors (See Supplementary Material for additional information).

Densities of $\left[{ }^{3} \mathrm{H}\right] \mathrm{MK}-801$ binding were measured by microdensitometry on film autoradiograms in frontal cortex (layers II-VI), and CA1 (oriens and pyramidal layers) and gyrus dentatus (GD, molecular layer) of the hippocampus (Fig. 1), and are summarized in Table 1. Statistical analysis (unpaired t-test, GraphPad Prism) revealed the absence of significant differences between the different 
groups analyzed. Covariance analysis (SPSS for Windows) indicated no influence of liver fibrosis in our sample (See Supplementary Material for detailed data).

Our results suggest that binding to frontal cortex and hippocampal NMDA receptors remains unaltered after chronic consumption of high doses of alcohol in the absence of clinical manifestations of alcoholism. Previous studies on hippocampal homogenates reported higher densities of $\left[{ }^{3} \mathrm{H}\right]$ glutamate binding in 5 alcoholics compared to 3 controls, with concomitant decreases in specific NMDA binding (Michaelis et al. 1990, 1993). Other authors (Dodd et al. 1992) found no differences in $\left.{ }^{3} \mathrm{H}\right] \mathrm{MK} 801$ binding in cortical membrane preparations between 10 alcoholics and 6 controls. Finally, Ridge et al. (2008) detected decreases in the expression of NR1, NR2A and NR2B NMDA receptor subunits in cerebral cortex only in cirrhotic alcoholics, but not in alcoholics without hepatic disease. Using receptor autoradiography, Freund \& Anderson (1996, 1999) found significant increments in binding in frontal cortex (13 abstinent alcoholics and 13 controls) when using $\left[{ }^{3} \mathrm{H}\right]$ glutamate and the selective NMDA antagonist $\left[{ }^{3} \mathrm{H}\right] \mathrm{CGP} 39653$. On the contrary, Cummins et al. (1990) showed reduced $\left[{ }^{3} \mathrm{H}\right]$ glutamate binding in hippocampus from 10 abstinent alcoholics.

Different reasons could explain the discrepancies between those data and our study. Clinical variations related to comorbidity such sudden death, cirrhosis, acute hypoxia or pneumonia could eventually alter glutamate binding (Piggott et al. 1992; Freund \& Anderson 1996; Ridge et al. 2008). In our sample, we did not find an influence of liver fibrosis (a necropsy finding without previous clinical manifestations), supporting the study of Ridge et al. (2008) that suggests that hepatopathy, but not alcohol per se, could be the cause of changes in NMDA receptors.

Another possible explanation is related to the ligand used. MK-801 binds inside the previously opened ion channel of the NMDA receptor and it has been demonstrated that ethanol diminishes $\left[{ }^{3} \mathrm{H}\right] \mathrm{MK} 801$ binding only in the absence of glycine, a modulator of channel aperture (Freund \& Anderson, 1996). Since we used intact, fresh-frozen brain tissue, it is possible that glycine present in our sections might interfere with the binding of $\left[{ }^{3} \mathrm{H}\right] \mathrm{MK} 801$ and therefore mask putative alterations present in samples from chronic alcohol consumers. 
It might be considered that ethanol could interact with NMDA receptors in a manner not measurable by autoradiographic techniques. For instance, a decrease in specific NMDA receptor subunits could eventually be compensated by an accelerated synthesis of mRNA encoding the proteins involved. Finally, it could be speculated that ethanol modifies other cellular events, such as the migration of receptor subunits from extrasynaptic sites in the plasmatic membrane to synaptic functional loci, or receptor assembly, among others.

Thus, a number of fundamental questions remain open, and further studies on a greater number of human brain samples are necessary. Combined studies of histological assessment with autoradiography with different ligands and in situ hybridization can yield information on the effects of chronic ethanol consumption on functional mature NMDA receptors and some of their subunits.

\section{ACKNOWLEDGMENTS}

We thank Dr. Félix Cruz-Sánchez at the Brain Bank of the Hospital Clinic (Barcelona) in the preparation and pathological examination of human brain material, and the staff of the Anatomical Phorensic Institute (IAF) of Barcelona. We wish to thank Dr. Emili Corbella for statistical analysis.

\section{REFERENCES}

Cummins JT, Sack M, von Hungen K (1990) The effect of chronic ethanol on glutamate binding in human and rat brain. Life Sci 47:877-882.

Dodd PR, Thomas GJ, Harper CG, Kril JJ (1992) Amino acid neurotransmitter receptor changes in cerebral cortex in alcoholism: effect of cirrhosis of the liver. J Neurochem 59:1506-1515.

Freund G and Anderson KJ (1996) Glutamate receptors in the frontal cortex of alcoholics. Alcohol Clin Exp Res 20:1165-1172.

Freund G and Anderson KJ (1999) Glutamate receptors in the cingulated cortex, hippocampus, and cerebellar vermis of alcoholics. Alcohol Clin Exp Res 23: 1-6. 
Hammarberg A, Jayaram-Lindström N, Beck O, Franck J, Reid MS (2009) The effects of acamprosate on alcohol-cue reactivity and alcohol priming in dependent patients: a randomized controlled trial. Psychopharmacology (Berl) 205:53-62.

Michaelis EK, Freed WJ, Galton N, Foye J, Michaelis ML, Phillips I, Kleinmann JE (1990) Glutamate receptor changes in brain synaptic membranes from human alcoholics. Neurochem Res 15:1055-1063.

Michaelis EK, Michaelis ML, Freed WJ, Foye J (1993) Glutamate receptor changes in brain synaptic membranes during chronic alcohol intake. Alcohol Alcohol 2:377-381.

Piggott MA, Perry EK, Saghal A, Perry RH (1992) Examination of parameters influencing [3H]MK-801 binding in postmortem human cortex. J Neurochem 58:1001-1008.

Ridge J, Ho A, Innes D, Dodd P (2008) The expression of NMDA receptor subunit mRNA in human chronic alcoholics. Ann NY Acad Sci 1139:10-19. 
Table 1. Densities of $\left[{ }^{3} \mathrm{H}\right] \mathrm{MK} 801$ binding in controls and alcohol consumers.

Data are mean densities of specific $\left[{ }^{3} \mathrm{H}\right] \mathrm{MK} 801$ binding expressed in fmol/mg tissue (mean \pm SD). No statistically significant differences were found among the different groups.

\begin{tabular}{|l|ccc|}
\hline Group & Frontal cortex & Dentate gyrus & CA1 \\
\hline Controls & $71.62 \pm 17.89(n=16)$ & $147.83 \pm 34.94(n=15)$ & $173.18 \pm 49.65(n=15)$ \\
Alcohol consumers (AC) all & $82.94 \pm 20.57(n=15)$ & $139.26 \pm 38.97(n=13)$ & $191.66 \pm 70.19(n=13)$ \\
$>80$ g/day consumers & $81.16 \pm 16.25(n=11)$ & $131.28 \pm 36.91(n=11)$ & $187.18 \pm 75.94(n=11)$ \\
$40-80$ g/day consumers & $87.86 \pm 32.39(n=4)$ & $183.14 \pm 6.92(n=2)$ & $216.29 \pm 4.61(n=2)$ \\
Abstinents & $79.71 \pm 4.35(n=3)$ & $124.36 \pm 18.93(n=4)$ & $165.75 \pm 42.56(n=4)$ \\
Non-abstinents & $83.75 \pm 23.05(n=12)$ & $145.88 \pm 44.53(n=9)$ & $203.17 \pm 78.90(n=9)$ \\
\hline
\end{tabular}




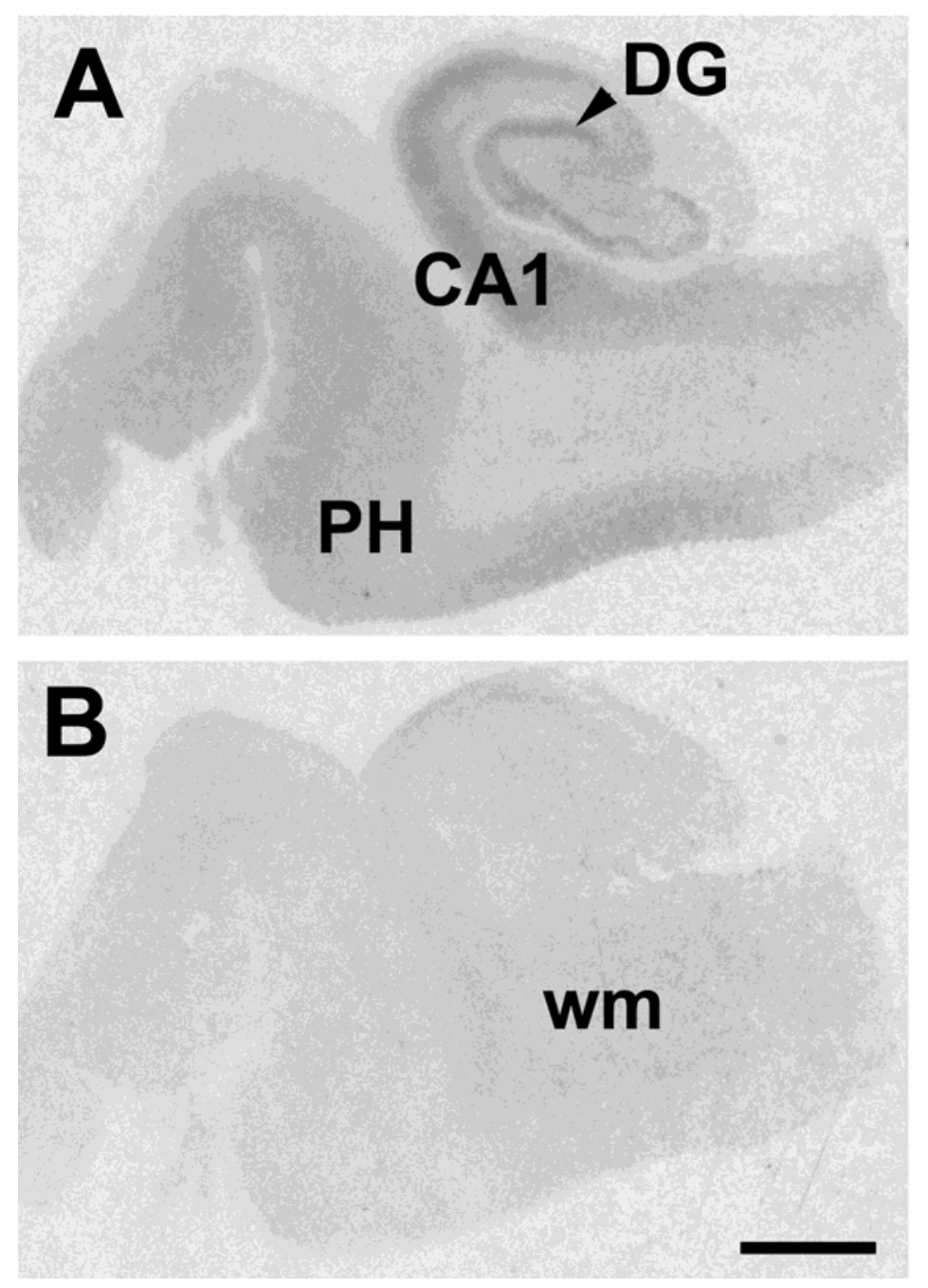

Figure I. Autoradiographic images showing the total (A) and non-specific (B) binding of $\left[{ }^{3} \mathrm{H}\right] \mathrm{MK} 801$ in the hippocampus of a control subject. CA1: CA1 field; DG: dentate gyrus; $\mathrm{PH}$ : parahippocampal gyrus; wm: white matter. Bar $=4 \mathrm{~mm}$. 


\section{Supplementary Material}

Cases. Studies were performed on 32 Caucasian subjects, 16 chronic alcohol consumers (AC) and 16 psychiatrically normal controls. Data related to alcohol consumption were obtained from medical records and confirmed by reports from close family members. History of alcohol consumption including length of abstinence before death was registered. All AC selected had not been not previously diagnosed of any alcohol associated disorder. Consequently, none fulfilled any criteria of alcohol dependence (DSM-IV) or diseases associated to alcoholism (ICD-10). Patients with a known history of neurological or psychiatric disorders or intravenous drug abuse were excluded. Detailed information on the individual characteristics of subjects, including alcohol consumption data, is summarized in Supplementary Table 1. Storage time of tissues was in all cases lower than three years. One case died after a gastrointestinal haemorrhage but did not present alterations in mesenteric and portal circulation that could suggest that the bleeding was from hepatic origin, as observed at autopsy.

Collection of brain samples and preparation for autoradiography. Brains were collected at autopsy at the Department of Pathology of the Hospital Clinic and the Forensic Anatomical Institute of Barcelona (Spain) within the first 28 hours after death. A standardized neuropathological evaluation was done on formalin-fixed blocks of each brain. In the AC group, no anatomical evidences of Wernicke-Korsakoff syndrome were found.

Once the brains were removed from the cranium, the right hemisphere was cut into approximately $2 \mathrm{~cm}$-thick blocks, which were immediately frozen on dry ice and kept at $-80^{\circ} \mathrm{C}$. Coronal sections $(14 \mu \mathrm{m}$ thick) were obtained from frozen blocks of frontal cortex and hippocampus using a microtome-cryostat (Leitz 1720, Germany), thaw-mounted onto glass slides previously coated with APTS and kept at $-20^{\circ} \mathrm{C}$ until use. Experiments were run following a matched-pair design so that each pair included sections from one alcoholic brain and its matched control. 
Supplementary material Table 1. Summary of cases

\begin{tabular}{|c|c|c|c|c|c|c|c|c|c|}
\hline Case & $\begin{array}{c}\text { Age } \\
\text { (years) }\end{array}$ & Sex & $\begin{array}{c}\text { PMI } \\
\text { (hours) }\end{array}$ & $\begin{array}{l}\text { Alcohol } \\
\text { (g/day) }\end{array}$ & Smoker & $\begin{array}{c}\text { Ethanol } \\
\text { abstinence } \\
\text { before } \\
\text { death }\end{array}$ & $\begin{array}{c}\text { Co- } \\
\text { morbidity }\end{array}$ & $\begin{array}{l}\text { Pathological } \\
\text { changes in } \\
\text { necropsy }\end{array}$ & $\begin{array}{c}\text { Cause of } \\
\text { death }\end{array}$ \\
\hline $\mathrm{C} 1$ & 45 & $M$ & 23.5 & None & Yes & - & - & - & Accident \\
\hline $\mathrm{C} 2$ & 43 & $M$ & 23.5 & None & Yes & - & - & - & CHD \\
\hline $\mathrm{C} 3$ & 69 & $M$ & 13.0 & None & Yes & - & - & - & CRA \\
\hline $\mathrm{C} 4$ & 74 & $M$ & 13.5 & None & Yes & - & $\mathrm{CHD}$ & - & $\mathrm{PE}$ \\
\hline $\mathrm{C} 5$ & 67 & $M$ & 9.5 & None & Yes & - & - & - & $\mathrm{CHD}$ \\
\hline C6 & 47 & $M$ & 16.0 & None & Yes & - & $\begin{array}{l}\text { Hepatitis C } \\
+\mathrm{HT}\end{array}$ & - & $\mathrm{CHD}$ \\
\hline $\mathrm{C} 7$ & 59 & $M$ & 6.0 & None & None & - & $\begin{array}{c}\text { Pulmonar } \\
\text { fibrosis }\end{array}$ & - & CRA \\
\hline $\mathrm{C} 8$ & 43 & W & 20.0 & None & None & - & - & - & Cancer \\
\hline C9 & 65 & $M$ & 15.0 & None & None & - & - & $\begin{array}{c}\text { Aortic } \\
\text { aneurism }\end{array}$ & $\mathrm{CHD}$ \\
\hline C10 & 74 & $\mathrm{M}$ & 16.0 & None & Yes & - & $\mathrm{CHD}$ & - & $\mathrm{CHD}$ \\
\hline C11 & 47 & $M$ & 16.0 & None & None & - & - & - & $\mathrm{CHD}$ \\
\hline $\mathrm{C} 12$ & 72 & $M$ & 20.0 & None & Yes & - & - & - & $\mathrm{CHD}$ \\
\hline C13 & 66 & W & 22.0 & None & Yes & - & $\mathrm{HT}$ & - & $\mathrm{CHD}$ \\
\hline C14 & 59 & $M$ & 12.0 & None & Yes & - & $\mathrm{CHD}$ & $\mathrm{CHD}$ & $\mathrm{CHD}$ \\
\hline C15 & 62 & $M$ & 22.0 & None & Yes & - & $\mathrm{CHD}$ & $\mathrm{CHD}$ & $\mathrm{CHD}$ \\
\hline C16 & 70 & $M$ & 19.0 & None & Yes & - & - & - & $\mathrm{CHD}$ \\
\hline $\mathrm{A} 1$ & 49 & $\mathrm{M}$ & 5.5 & $40-80$ & No & NO & - & - & Traumatism \\
\hline$A 2$ & 57 & $M$ & 27.0 & $>80$ & No & NO & Tuberculosis & - & CRA \\
\hline A3 & 44 & $M$ & 21.0 & $>80$ & Yes & YES & COPD & - & CRA \\
\hline A4 & 67 & $M$ & 16.0 & $>80$ & Yes & YES & - & Liver fibrosis & CRA \\
\hline A5 & 50 & $M$ & 28.0 & $>80$ & No & NO & - & - & Sudden death \\
\hline A6 & 66 & $M$ & 23.0 & $40-80$ & Yes & NO & $\begin{array}{l}\text { Diabetes } \\
\text { mellitus }\end{array}$ & - & Sudden death \\
\hline A7 & 34 & $M$ & 28.0 & $>80$ & None & NO & - & - & CRA \\
\hline A8 & 43 & $M$ & 24.0 & $>80$ & Yes & NO & - & - & CRA \\
\hline A9 & 66 & $M$ & 11.0 & $>80$ & None & NO & $\begin{array}{l}\text { Diabetes } \\
\text { mellitus }\end{array}$ & - & Traumatism \\
\hline A10 & 72 & $M$ & 20.0 & $40-80$ & Yes & NO & $\mathrm{HT}$ & - & $\mathrm{CHD}$ \\
\hline A11 & 74 & $M$ & 24.5 & $40-80$ & None & NO & - & Liver fibrosis & Sudden death \\
\hline A12 & 51 & $M$ & 21.5 & $>80$ & Yes & NO & - & - & Sudden death \\
\hline A13 & 63 & $M$ & 23.5 & $>80$ & None & NO & $\mathrm{CHD}$ & - & Sudden death \\
\hline A14 & 56 & $M$ & 10.0 & $>80$ & Yes & YES & - & Liver fibrosis & $\mathrm{CHD}$ \\
\hline A15 & 73 & $M$ & 14.0 & $>80$ & Yes & NO & COPD & - & $\mathrm{GIH}$ \\
\hline A16 & 64 & $M$ & 6.0 & $>80$ & None & YES & - & - & $\mathrm{CHD}$ \\
\hline
\end{tabular}


(Supplementary table 1): A: Alcohol consumers; C: Controls; CHD: Coronary heart disease; COPD: Chronic obstructive pulmonary disease; CRA: Cardio-respiratory arrest; GIH:

Gastrointestinal hemorrhage; HC: Hepatic cirrhosis; HT: Hypertension; M: Man; PE: Pulmonary embolism.; PMI: Postmortem interval; W: Woman

\section{Quantitative receptor autoradiography for NMDA receptor binding.} Incubation with [ $\left.{ }^{3} \mathrm{H}\right] \mathrm{MK}-801$ was performed as described previously (Gulya et al., 1991). For each brain block, three consecutive sections were used, two for the determination of total binding and one for the nonspecific binding. Slidemounted tissue sections were preincubated for $30 \mathrm{~min}$ in $50 \mathrm{mM}$ Tris- $\mathrm{HCl}$ buffer $\left(\mathrm{pH} 7.4\right.$ at $\left.25^{\circ} \mathrm{C}\right)$. Afterwards the slides were incubated for $120 \mathrm{~min}$ at $25^{\circ} \mathrm{C}$ in Tris-HCl buffer containing $\left.20 \mathrm{nM}{ }^{3} \mathrm{H}\right] \mathrm{MK} 801$ (250.63 Ci/mmol; NEN DuPont, Boston, MA, USA). Nonspecific binding was determined in the presence of $2 \mu \mathrm{M}$ unlabeled MK801. After incubation, the slides were given three 1-min rinses in Tris- $\mathrm{HCl}$ buffer. The sections were then rapidly dried under a stream of cold air.

Autoradiograms were obtained by apposing the sections against ${ }^{3} \mathrm{H}$-sensitive film (Amersham Hyperfilm- $\left[{ }^{3} \mathrm{H}\right]$, Amersham, UK) for 5 weeks at $4{ }^{\circ} \mathrm{C}$. The film was co-exposed with sets of tritiated microscale standards (calibrated in $\mathrm{nCi} / \mathrm{mg}$ tissue) ( ${ }^{3} \mathrm{H}$-Microscales, Amersham). The autoradiograms were developed and fixed with Kodak developer and fixer at $18{ }^{\circ} \mathrm{C}$. Sections were also stained with cresyl violet for anatomical reference and identification of the structures.

The densities of $\left[{ }^{3} \mathrm{H}\right] \mathrm{MK} 801$ binding were measured by microdensitometry in layers II-VI of the frontal cortex, the molecular layer of the gyrus dentatus, and oriens and pyramidal layers of the CA1 hippocampal field using a computerized image analysis system (MCID-M4, Imaging Researh Inc., St. Catharines, Ontario, Canada). Standardization curves derived from the tritiated standards were used to convert optical density readings of the autoradiograms into nCi/mg of tissue equivalents and transformed to $\mathrm{fmol}$ of bound $\left[{ }^{3} \mathrm{H}\right] \mathrm{MK} 801 / \mathrm{mg}$ protein. Non-specific binding was homogeneous and low in all regions. Images were enlarged ca. x20 with a zoom to obtain a resolution that could allow discriminating among hippocampal layers. Five measures were taken from each structure in every sample and the corresponding means were considered as 
single density data points. The non-specific binding was subtracted from the mean of total binding densities obtained in duplicate sections.

Statistical analysis. We used descriptive statistics with means and standard deviations for the baseline characteristics of the patients. Comparisons of binding densities between groups were done using the unpaired t-test, since the variables showed a normal distribution according to the results of the Kolmogorov-Smirnov test (GraphPad, Prism). All statistical tests were 2-tailed, and the significance level was 0.05 .

In order to rule out significant changes on binding data secondary to variables such as age, gender, PMI, storage time, alcohol consumption, hepatic fibrosis, benzodiazepine consumption, smoking history, sudden death, we performed a covariance analysis for the three regions studied (SPSS 14.0, SPSS Inc., Chicago, Illinois).

\section{Subject clinical data}

Covariance analysis of our data indicated that consumption low doses of benzodiazepines at night for sleeping disturbances reported for two cases, had no influence on binding data. According to this analysis there was an effect of sudden death on the statistical results which would need to be further confirmed.

\section{Alcohol abstinence:}

Several studies have shown that chronic ethanol ingestion produces increases in MK-801 binding to NMDA receptors in rat brain, and that the persistence of changes in MK-801 binding runs in parallel with the time-course for ethanol withdrawal seizure susceptibility, usually 24 hours (Gulya et al. 1991). In contrast, the human timing for the development of clinical withdrawal is more prolonged. The clinical manifestations can begin in a period between few hours and two days after alcohol cessation and then increment during the next days, when the patient can suffer severe symptomatology such as delirium tremens (MacKeon et al. 2008). Due to these chronologic differences between human and rodents, we considered alcohol consumers as non-abstinents when they had ingested alcohol less than $12 \mathrm{~h}$ before death, since it is unlikely that they 
would undergo a withdrawal situation that could eventually involve acute changes in NMDA receptors.

\section{References}

Gulya, K; Grant, KA; Valverius, P; Hoffman, PL; Tabakoff, B. (1991) Brain regional specificity and time-course of changes in the NMDA receptorionophore complex during ethanol withdrawal. Brain Res.;547: 129-134.

McKeon A, Frye MA, Delanty N (2008) The alcohol withdrawal syndrome. J Neurol Neurosurg Psychiatry 79:854-862. 